DOI

\title{
ФЕНОЛОГІЧНІ СПОСТЕРЕЖЕННЯ ЗА РОЗВИТКОМ ВЕРОНІКИ ЛІКАРСЬКОЇ
}

\author{
() І. І. Мілян ${ }^{1}$, М. В. Мельник², С. М. Марчишин${ }^{1}$, С. Ю. Чолач ${ }^{1}$
}

${ }^{1}$ Тернопільський державний медичний університет імені І. Я. Горбачевського

${ }^{2}$ ДВНЗ “Івано-Франківський національний медичний університет”

Резюме: вивчено особливості розвитку вероніки лікарської в умовах культури.

Ключові слова: вероніка лікарська, трава, фенологічні спостереження.

Вступ. Вероніка лікарська - дикоросла рослина родини ранникові (Scrophulariaceae). Росте на піщаних грунтах у світлих лісах по всій Україні, рідше у Лісостепу і Криму, дуже рідко в Степу. Вероніка належить до видів, які зустрічаються на узліссях, галявинах, зрубах, лісових луках, серед чагарників [3].

Рослину здавна використовують у народній медицині як протизапальний, знеболювальний, протисудомний, антитоксичний, фунгіцидний, кровоочисний, відхаркувальний, депуративний, кровоспинний і ранозагоювальний засіб [2].

Природні запаси вероніки лікарської 3 кожним роком зменшуються внаслідок інтенсивного господарського використання земель, на яких зростає рослина, заготівлі сировини без урахування норм та правил збору, несприятливої екологічної ситуації, зокрема після аварії на Чорнобильській AEC та інших факторів. При цьому попит фрармацевтичної промисловості України на сировину дикорослих лікарських рослин залишається великим [6]. Тому метою нашої роботи є вивчення особливостей розвитку вероніки лікарської в умовах культури.

Методи дослідження. Фенологічні спостереження проводили за методикою Держкомісії із сорто- випробовування сільськогосподарських культур на дослідних ділянках та в природньому фрітоценозі в 3-10-кратній повторності [1].

Аналізуючи структуру морфогенезу вероніки лікарської вивчали особливості фрормування і тривалість життя материнського куща. Рослини висаджували (16 квітня) в грунт з міжряддями 45 × 70 см.

Результати й обговорення. Вероніка лікарська багаторічна опушена рослина висотою 10-30 см, яка розмножується насінням і вегетативно - живцями та вкоріненими ділянками втеч. Насіння можна сіяти під зиму або навесні. Цікаве у вероніки пристосування до поширення насіння. У суху погоду двогніздна коробочка закрита, а в дощ відкривається, вода вимиває 3 неї насіння і розносить його на значну відстань [4]. Плодоносить вероніка в серпні - вересні.

Культивування вероніки лікарської проводили відповідно до належної практики культивування та збирання вихідної сировини рослинного походження введеної в дію наказом № 118 МОЗ України від 14.02.2013 р. [5].

Ювенільна та іматурна фрази у вероніки лікарської чітко не окреслені, поступово спостерігаються зміни фрорми листків (рис. 1).
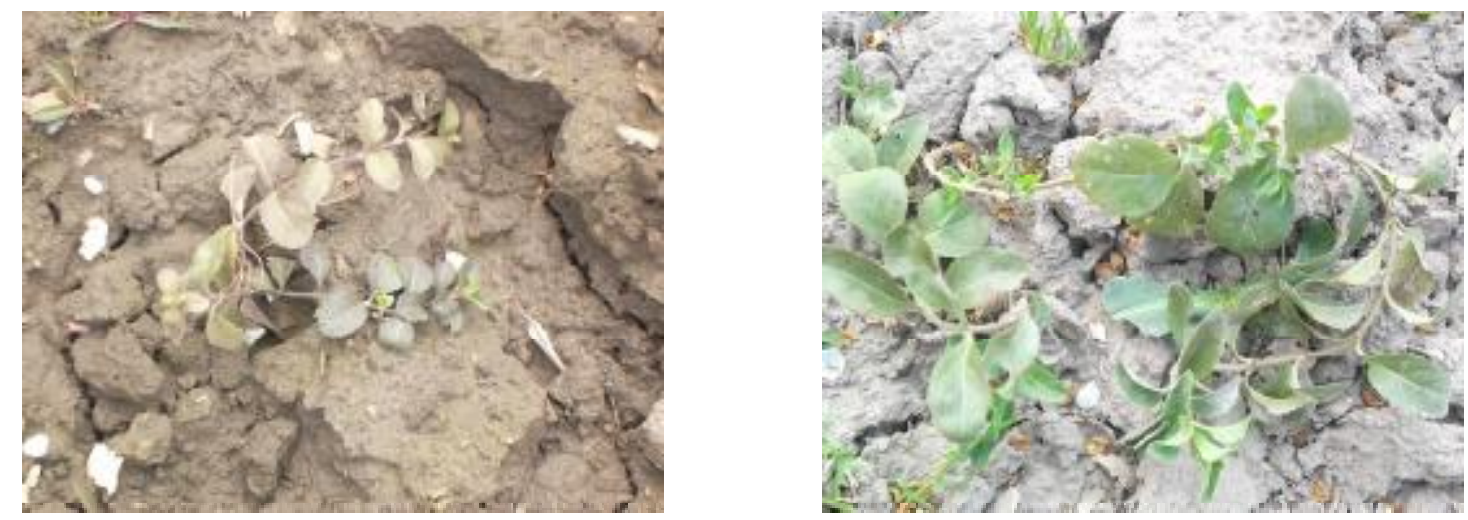

Рис. 1. Початок відростання вероніки лікарської на дослідних ділянках. 


\section{Phytochemical researches}

Генеративна фраза починається з утворення бутонів. Поява перших бутонів збігається 3 періодом інтенсивного росту - 3 першої декади червня до третьої декади червня.

Фаза бутонізації продовжується до розпускання першої квітки. У цей період дещо знижується ростова активність рослини.

Тип розпускання суцвіття - рецимозний, що характеризується випереджальним розкриттям найнижчої квітки й акропетальним порядком розвитку інших квіток. Встановлено, що добовий хід розпускання квіток у рослин однотипний. Зміна добового ритму цвітіння залежить від температури й вологості повітря. Оптимальними умовами для розпускання квіток можна вважати температуру повітря $18-22{ }^{\circ} \mathrm{C}$ і вологість повітря 50 - $60 \%$, при яких у ранкові години спостерігається максимальне число квіток, що розпустилися.

За початок цвітіння приймали розкриття перших квіток у 5-15 рослин. Масове цвітіння відзначали, якщо більше 30 \% бутонів рослин перетворювалися у квіти. Кінець цвітіння видзначали, коли тільки на деяких рослинах залишалися квіти. Середня тривалість цвітіння в природних умовах складала 20 днів. У природному фрітоценозі (рис. 2) у вероніки лікарської по-

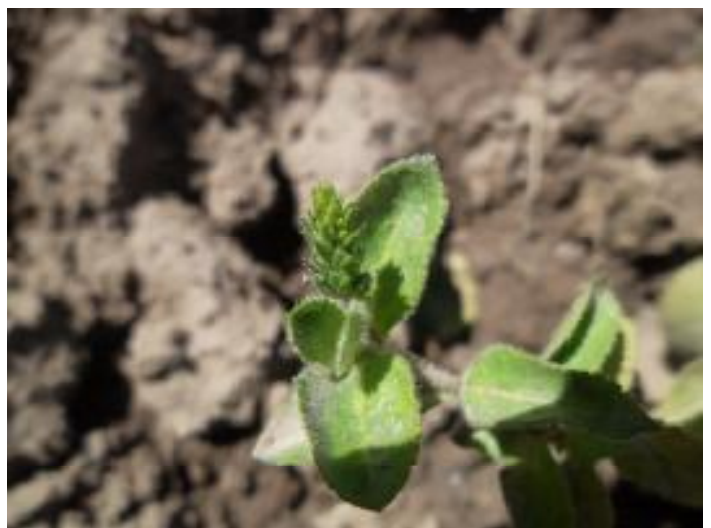

A

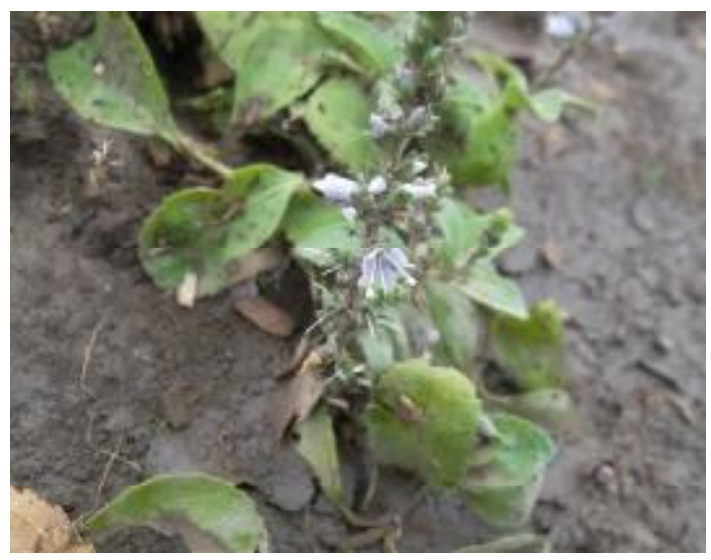

B чинається з запізнення всіх фраз розвитку. У вероніки лікарської поява бутонів запізнюється на 7-10 днів порівняно з дослідною ділянкою. Фаза цвітіння вероніки лікарської у природному фрітоценозі запізнюється на 10 днів.

Якщо після цвітіння генеративні пагони видалити, то наприкінці серпня настає друга, менш інтенсивна хвиля цвітіння.

Результати проходження френологічних фраз розвитку вероніки лікарської наведено в таблиці 1.

Після запліднення настає фраза росту і фрормування, а далі наливу й дозрівання насіння. Дозрівання супроводжується поступовим зневодненням рослини, відсиханням листків і стебел. Засихання рослини відбувається не відразу, а починається ще в період масового цвітіння, коли дозріває насіння в нижній частині суцвіття.

Фаза плодоношення включає три етапи: молочну, воскову та повну стиглість. Молочна стиглість характеризується опаданням віночків і утворенням зав'язей.

Дозрівання коробочок проходить поетапно. Воскова стиглість коробочок вероніки лікарської на дослідних ділянках (рис. 3) спостерігалась у другій декаді

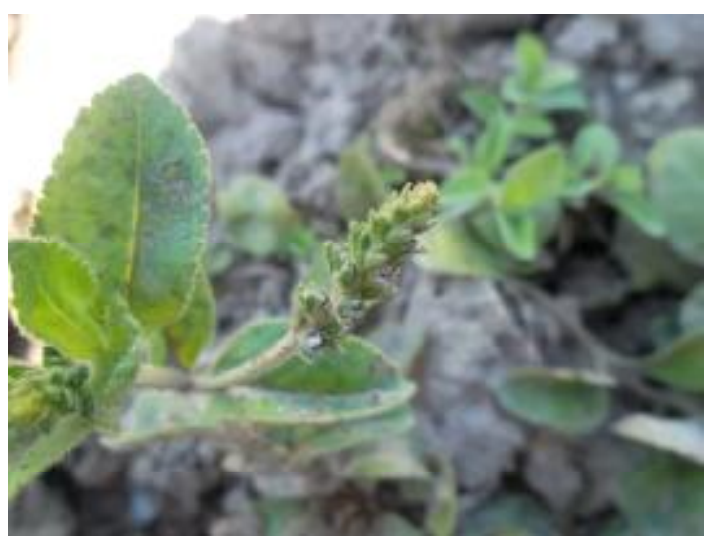

Б

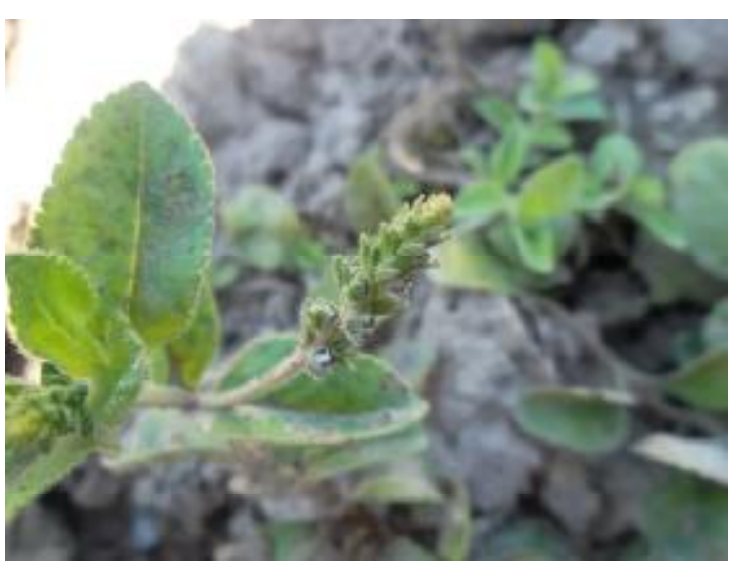

$\Gamma$

Рис. 2. Вероніка лікарська фраза цвітіння: А - бутонізація, Б - початок цвітіння, В - масове цвітіння, Г - кінець цвітіння.

ISSN 2312-0967. Фармацевтичний часопис. 2015. № 4 
Фітохімічні дослідження Phytochemical researches

Таблиця 1. Проходження френофаз вероніки лікарської

\begin{tabular}{|c|c|c|c|c|c|c|}
\hline \multirow{2}{*}{ Фенологічні фрази } & \multirow{2}{*}{ Етапи органогенезу } & \multirow{2}{*}{$\begin{array}{c}\text { Початок і кінець } \\
\text { фази }\end{array}$} & \multicolumn{4}{|c|}{ Тривалість френофрази, місяць } \\
\hline & & & V & VI & VII & VIII \\
\hline $\begin{array}{l}\text { Початок } \\
\text { відростання }\end{array}$ & $\begin{array}{c}\text { Утворення } \\
\text { прикореневої розетки, } \\
\text { стебла, справжніх } \\
\text { листочків }\end{array}$ & $\begin{array}{c}\text { Фаза відростання } \\
\text { стебла }\end{array}$ & 18 днів & - & - & - \\
\hline Вегетативний ріст & $\begin{array}{c}\text { Диференціація } \\
\text { зачаткового суцвіття, } \\
\text { формування бутонів та } \\
\text { їх вихід із бруньки }\end{array}$ & $\begin{array}{c}\text { Від 5-6 до } \\
\text { 8-9 пар справжніх } \\
\text { листків }\end{array}$ & & $\begin{array}{c}14-25 \\
\text { днів }\end{array}$ & - & - \\
\hline Бутонізація & $\begin{array}{c}\text { Формування пиляків та } \\
\text { зав'язі }\end{array}$ & $\begin{array}{c}\text { Від 8-9 пар } \\
\text { справжніх листків } \\
\text { до розпускання } \\
\text { першої квітки }\end{array}$ & - & $\begin{array}{l}9-12 \\
\text { днів }\end{array}$ & - & - \\
\hline Цвітіння & Розпускання квіток & Початок - кінець & - & $\begin{array}{c}15-25 \\
\text { днів } \\
\end{array}$ & - & \\
\hline Плодоношення & $\begin{array}{c}\text { Формування і } \\
\text { дозрівання плодів }\end{array}$ & $\begin{array}{c}\text { Від побуріння } \\
\text { нижньої частини } \\
\text { суцвіття }\end{array}$ & - & - & $\begin{array}{c}26-36 \\
\text { днів }\end{array}$ & \\
\hline
\end{tabular}

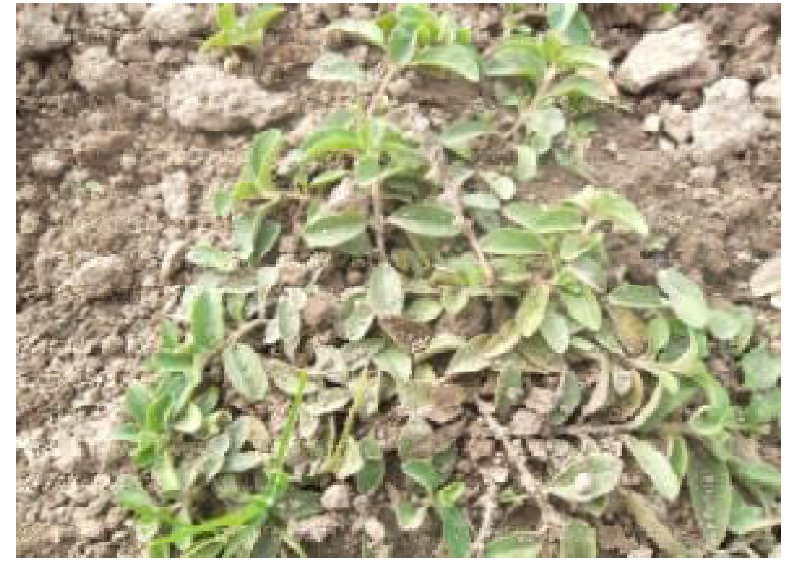

A

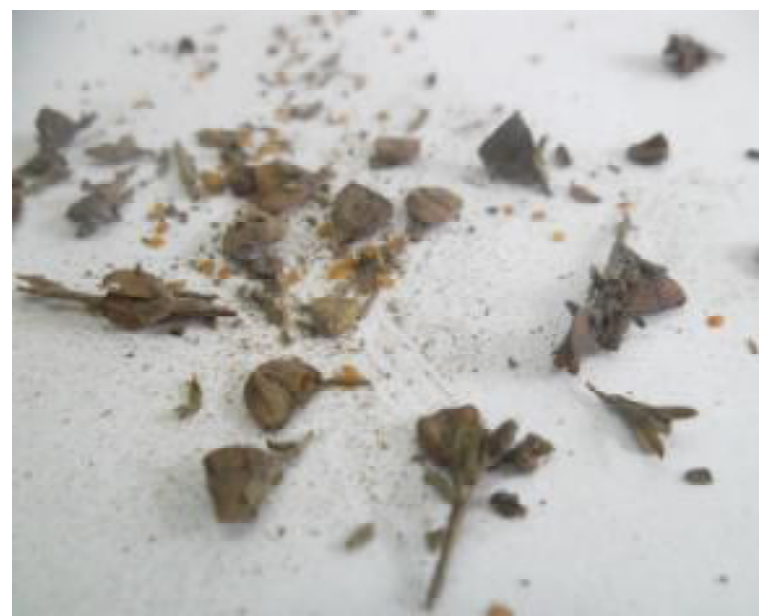

B
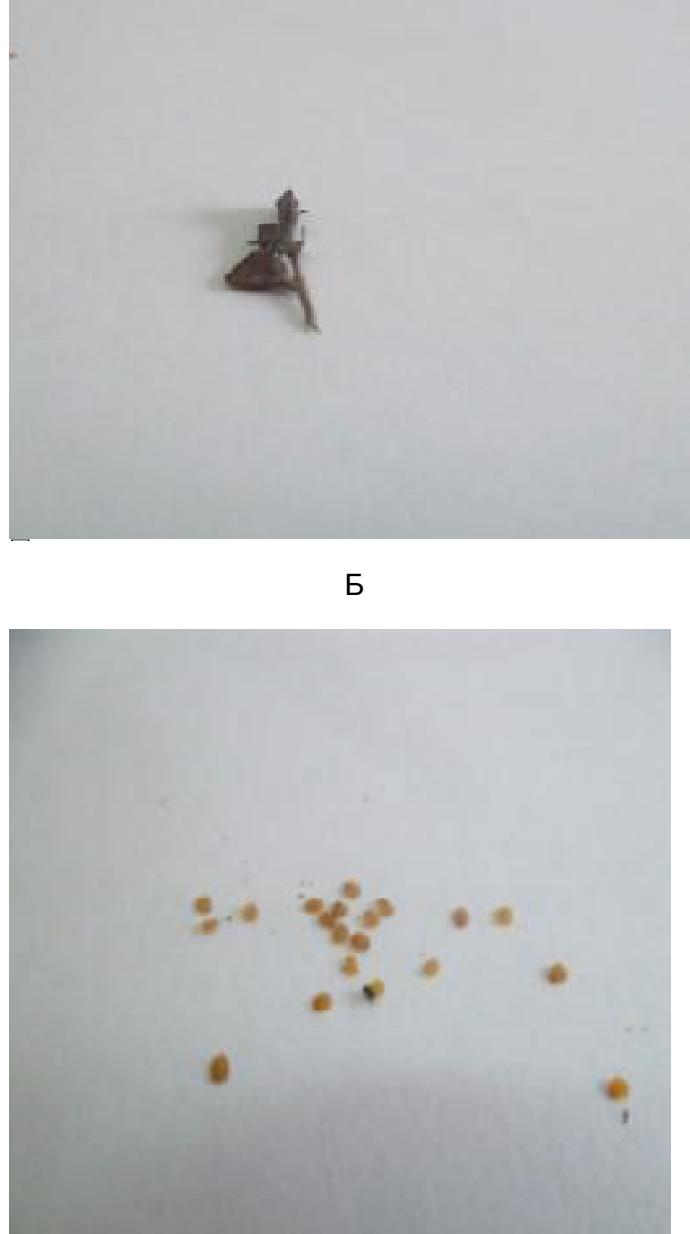

$\Gamma$

Рис. 3. Фаза плодоношення вероніки лікарської: A - молочна стиглість, Б - воскова стиглість, В - повна стиглість, Г- дозріле насіння.

ISSN 2312-0967. Pharmaceutical review. 2015. № 4 
Фітохімічні дослідження

\section{Phytochemical researches}

липня, у природних умовах - у першій декаді серпня. Середня тривалість дозрівання коробочок на дослідних ділянках складає в середньому - 26 днів, у природному фрітоценозі - 36 днів. Заготівлю насіння проводили в стадії повної стиглості. Висота рослин коливалась в межах 15 - $30 \mathrm{~cm}$.

Залежно від місця зростання та метеорологічних умов, спостерігали значні відмінності усіх френологічних фраз. Так, рослини вероніки лікарської, які зростають у природних умовах, запізнюють початок відростання, цвітіння, плодоношення в середньому на
10-15 днів. При френологічних спостереженнях на дослідних ділянках рослини вероніки лікарської відмінності у настаннях фраз розвитку незначні. Це свідчить про те, що рослини, які зростають у однакових абіотичних та едасрічних умовах, мають однотипне настання усіх фраз органогенезу.

Висновок. У результаті проведених фенологічних спостережень встановлено, що для створення сприятливих умов розвитку вероніки лікарської на дослідних ділянках необхідно враховувати тип ґрунту, забезпеченість вологою, освітлення та ін.

\section{Список літератури}

1. Бейдеман И.Н. Методика изучения фенологии растений и растительных сообществ / И. Н. Бейдеман. Новосибирск : Наука, 1974. - 155 с.

2. Травник. Лучшие рецепты народной медицины / М. А. Изотова, Т. Ф. Плотникова, Ю. И. Кирова, Н. А. Сарафранова. - М. : Эксмо, 2009. - 896 с.

3. Мінарченко В. М. Ресурсна значущість видів лікарських рослин України / В. М. Мінарченко, Т. П. Гарник // Фітотерапія. - 2013. - № 4. - С. 37-40.

4. Морозюк С. С. Альбом з ботаніки / С. С. Морозюк, В. В. Протопопова. - К. : Радянська школа, 1979. - 151с. 5. Про внесення змін до наказу МОЗ України від 16 лютого 2009 року № 95: наказ МОЗ України № 118 від 14.02.2013р. [Електронний ресурс] Режим доступу до інф.: https://www. moz.gov.ua/ua/portal/dn_20130214_0118. html

6. Рослинний світ та лісові ресурси [Електронний ресурс] Режим доступу до інф.: http://ukrmodno.com.ua/ health/1-roslinnij-svit-ta-lisovi-resursi/ main.html

\section{ФЕНОЛОГИЧЕСКИЕ НАБЛЮДЕНИЯ ЗА РАЗВИТИЕМ ВЕРОНИКИ ЛЕКАРСТВЕННОЙ}

\section{И. И. Милян ${ }^{1}$, М. В. Мельник², С. М. Марчишинн, С. Ю. Чолач ${ }^{1}$}

${ }^{1}$ Тернопольский государственный медицинский университет имени И. Я. Горбачевского

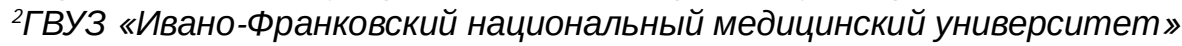

Резюме: изучены особенности развития вероники лекарственной в условиях культуры.

Ключевые слова: вероника лекарственная, трава, френологические наблюдения.

\section{THE PHENOLOGICAL OBSERVATIONS OF VERONICA OFFICINALIS DEVELOPMENT}

\section{I. Milian' ${ }^{1}$, M. V. Melnyk ${ }^{2}$, S. M. Marchyshyn ${ }^{1}$, S. Yu. Cholach ${ }^{1}$}

${ }^{1}$ Ternopil State Medical University by I. Ya. Horbachevsky

${ }^{2}$ SHEI «Ivano-Frankivsk National Medical University»

Summary: the development distinctions of Veronica officinalis in a culture was studied.

Key words: Veronica officinalis, herb, phenological observations. 